\title{
Pemberdayaan Masyarakat Desa Yang Buta Huruf
}

\author{
Syamsiah \\ Hidayah Quraisy \\ Universitas Muhammadiyah Makassar \\ hidayahquraisy@unismuh.ac.id \\ Rosleny Babo \\ Universitas Muhammadiyah Makassar \\ roslenybabo@unismuh.ac.id
}

\begin{abstract}
ABSTRAK
Penelitian ini menggunakan jenis penelitian deskriftif kualitatif dan teknik Purposive Sampling.ditunjang pengumpulan data dilakukan dengan cara observasi, wawancara, teknik dokumentasi dari hasil foto dan arsip yang dimiliki pemerintah setempat. Dalam penelitian ini Pemerintah setempat, pengelolah, tutor atau pengajar, dan masyarakat yang buta huruf di desa Bontomarannu yang dianggap bisa memberikan informasi atau data yang sesuai dengan penelitian.Berdasarkan penelitian yang telah penulis lakukan, maka dapat disimpulkan bahwa apa yang diharapkan oleh pemerintah dengan diselenggarakannya program Pemberdayaan masyarakat desa yang buta huruf telah tercapai, yaitu adanya kemajuan warga belajar dalam bidang sosial maupun ekonomi. Secara sosial, masyarakat yang dulunya buta huruf sekarang mampu membaca, menulis, dan berhitung. Sedangkan secara ekonomi, masyarakat mampu berwirausaha secara mandiri dengan menerapkan materi keterampilan fungsional yang telah diberikan pada waktu proses pembelajaran program pengentasan buta huruf yang dilaksanakan oleh PKBM (Pusat Kegiatan Belajar Masyarakat) Satria Galesong.
\end{abstract}

Kata Kunci : Pemberdayaan, Masyarakat, Buta Huruf.

\section{PENDAHULUAN}

Pendidikan adalah hal yang utama didalam kehidupan era sekarang ini.Pendidikan dapat diperoleh melalui jalur pendidikan formal dan pendidikan non formal.Ilmu pengetahuan, keterampilan, dan pendidikan merupakan unsur dasar yang menentukan kecekatan seseorang berpikir tentang dirinya dan lingkungannya.Melihat kondisi pendidikan di Indonesia, masih perlu dilakukan pembenahan diberbagai bidang pendidikan.Dilihat dari ruang lingkup di Indonesia yang sempit ini, masih saja ada masyarakat yang terbelakang yaitu masih banyak masyarakat yang menyandang status buta huruf.Dalam kurun waktu beberapa tahun, nampak bahwa usaha pemerintah daerah untuk menurunkan angka buta huruf tidak selalu berhasil di semua daerah.Secara nasional, Sulawesi Selatan bahkan masuk dalam kategori daerah dengan angka buta huruf yang masih tinggi.Yang terjadi malah sebaliknya; angka buta huruf mengalami kelonjakan. Tentunya kelonjakan itu disebabkan oleh berbagai faktor, antara lain adanya 
buta huruf baru, putus sekolah formal yang buta huruf kembali, dan hasil garapan pemberantasan buta huruf yang tidak tuntas dan hanya menyebut secara kualitas saja.

Sebelum dilaksanakan program pemberdayaan masyarakat desa yang buta huruf maka dilakukan sosialisasi dan pendataan terlebih dahulu untuk mengetahui tingkat buta huruf masyarakat Bontomarannu. Unit Pelaksana Teknis Daerah Dinas Pendidikan Kecamatan Galesong Selatan bersama PKBM merupakan wadah pemberdayaan masyarakat di tingkat kecamatan yang perlu menggalakkan program Pemberantasan Buta Huruf dengan melakukan berbagai strategi pemberdayaan masyarakat dan membekali warga belajar dengan keterampilan guna meningkatkan kualitas sumber daya manusia.Salah satu bantuan dan program yang telah diupayakan pemerintah dalam meningkatkan pengetahuan masyarakat termasuk di antaranya adalah program pemberantasan Buta huruf (atau sekarang disebut dengan Keaksaraan Fungsional) melalui kelompok belajar. Akan tetapi, tidak semua peserta yang mengikuti kegiatan di kelompok belajar tersebut melanjutkan ke program selanjutnya, yaitu lanjut ke program Paket A setara SD. Hal ini disebabkan oleh berbagai hal, di antaranya adalah warga belajar merasa cukup setelah bisa membaca dan menulis. Padahal warga belajar harus terus meningkatkan kemampuannya tersebut dengan mempelajari pelajaran yang tingkatannya lebih sulit lagi. Selain itu keterbatasan sarana belajar yang tersedia di desa, terbatasnya sumber daya manusia yang tersedia, terbatasnya dana pemerintah untuk menyelenggarakan kegiatan pembelajaran di masyarakat atau faktor keengganan masyarakat memperparah keadaan yang membuat masyarakat tetap buta huruf.Menjadi Faktor utama yang membuat masyarakat buta huruf di Desa Bontomarannu Kecamatan Galesong Selatan adalah kemiskinan, ekonomi, berbagai jenis penyakit fisik dan mental, dan anggapan orang tua bahwa sekolah itu tidak penting, sehingga banyak anak-anak remaja yang tidak sekolah, ada juga putus sekolah disebabkan pengaruh uang, mereka lebih mementingkan mencari uang dari pada mencari ilmu.

Salah satu desa yang ada di Kecamatan Galesong Selatan Kabupaten Takalar yang penduduknya masih banyak terdapat ibu-ibu dan bapak-bapak yang buta huruf serta remaja yang usia 15 tahun ke atas karena tidak adanya dukungan dari orang tua mereka untuk sekolah sehingga mereka lebih memilih untuk membantu orang tuanya mencari nafkah.Pemberdayaan sangat identik dengan pendidikan dan merupakan hakikat pendidikan itu sendiri, apa yang disebut dengan pendidikan termasuk pendidikan luar sekolah atau pendidikan nonformal adalah usaha memberdayakan manusia, memampukan manusia, mengembangkan talenta-talenta yang ada pada diri manusia agar dengan 
kemampuan dan potensi yang dimilikinya dapat dikembangkan melalui pendidikan dan pembelajaran.

\section{LANDASAN TEORI}

Robinson (1994) menjelaskan bahwa pemberdayaan adalah suatu proses pribadi dan sosial; suatu pembebasan kemampuan pribadi, kompetensi, kreatifitas dan kebebasan bertindak. Sedangkan Ife (1995) dalam Oos M Anwas (2014: 49), mengemukakan bahwa pemberdayaan adalah menyiapkan kepada masyarakat berupa sumber daya, kesempatan, pengetahuan dan keahlian untuk meningkatkan kapasitas diri masyarakat didalam menentukan masa depan mereka, serta berpartisipasi dan mempengaruhi kehidupan dalam komunitas masyarakat itu sendiri.Tujuan Dan Sasaran Pemberdayaan merupakan upaya meningkatkan harkat lapisan masyarakat dan pribadi manusia. Upaya ini meliputi (1) Mendorong, memotivasi, meningkatkan kesadaran akan potensinya dan menciptakan iklim dan suasana untuk berkembang. (2) Memperkuat daya, potensi yang dimiliki dengan langkah-langkah positif dalam memperkembangkannya. (3) Penyediaan berbagai masukan dan pembukaan akses kepeluang-peluang. Upaya pokok yang dilakukan dalam pemberdayaan adalah peningkatan taraf pendidikan, derajat kesehatan, akses kepada modal, teknologi tepat guna, informasi, lapangan kerja dan pasar, dan fasilitas-fasilitas yang ada.

Jabal Arfa, 2002:4 Desa adalah suatu wilayah yang ditempati oleh sejumlah penduduk sebagai kesatuan masyarakat hukum yang mempunyai organisasi pemerintahan terendah langsung dibawah camat dan berhak menyelenggarakan rumah tangganya sendiri dalam ikatan negara Kesatuan Republik Indonesia.Pandangan Paulo Freire ( 1999: 90), orang yang buta huruf adalah orang marginal, kata ini mengandung makna pasif, artinya bahwa orang yang buta huruf merupakan orang yang dimarginalkan atau diasingkan dari masyarakat karena tidak mungkin mereka terpinggirkan tanpa memisalkan adanya alasan yang jelas. Ada dua anggapan bahwa apabila marginalitas itu sebuah pilihan yang tidak lepas dari permasalahan mereka: kelaparan, penderitaan, berbagai jenis penyakit fisik dan mental, kematian, kriminal. Freire (1972), Desakan ekonomi, kesadaran terhadap pendidikan masih rendah, jumlah anggota keluarga yang banyak, persaingan kehidupan dan kekurang mampuan dalam menghadapi kehidupan merupakan faktor yang menimbulkan anak putus sekolah atau tidak mampu untuk sekolah sehingga timbulnya warga yang buta huruf.Akhirnya, mereka pasrah dalam 
keadaan kondisi tersebut (fatalism) sehingga terdiam dalam kebuta aksaraannya (silent culture).

Kusnadi ( 2005 : 36-47), faktor-faktor yang menyebabkan buta huruf (buta aksara). Beberapa penyebab buta aksara dapat diidentifikasi sebagai berikut:(a) Kemiskinan penduduk merupakan ketidak mampuan seseorang memenuhi kebutuhan sehari-harinya termasuk pendidikan dan faktor ekonomi keluarga sehingga mereka tidak mampu sekolah dan banyaklah masyarakat yang buta huruf. (b) Putus sekolah dasar (SD). (c) Drop out program PLS. (d) Kondisi sosial masyarakat di antaranya: Kesehatan dan gizi masyarakat, Demografis dan geografis, Aspek sosiologis, dan Issue gender. (e) Penyebab struktural yaitu: Skala makro, skala mikro, dan aspek kebijakan.

Menurut Sajogyo dalam (Prayitno \& Lincolin Arsyad, 1987: 98) kemiskinan adalah suatu tingkat kehidupan yang berada di bawah standar kebutuhan hidup minimun yang ditetapkan berdasarkan atas kebutuhan pokok pangan yang membuat orang cukup bekerja dan hidup sehat berdasar atas kebutuhan beras dan kebutuhan gizi.Buta Huruf dapat diselesaikan dengan berbagai cara, di antaranya dengan: (1) Mengurangi jumlah anak yang tidak bersekolah. Pemerintah harus berupaya untuk menekan anak usia sekolah yang tidak sekolah dan putus sekolah yang diakibatkan oleh masalah kemiskinan, maupun yang diakibatkan oleh jauh dari layanan pendidikan. (2) Membuat cara-cara baru dalam proses pembelajaran. Membuat cara-cara yang baru yang asyik agar peserta didik tidak bosan untuk belajar dan menjaga kemampuan beraksara bagi peserta didik. (3) Adanya niat baik dan sungguh-sungguh dari pemerintah. Pemerintah harus mempunyai niat yang baik, sungguh-sungguh dan serius untuk memberantas buta huruf untuk mencerdaskan kehidupan bangsa dan untuk meningkatkan Indeks Pembangunan Manusia. (4) Perlunya keterlibatan berbagai pihak dalam upaya percepatan pemberantasan buta huruf. Pemberantasan buta huruf bukan saja tugas pemerintah semata tapi itu tugas kita semua selaku generasi penerus bangsa. Jadi semua pihak harus berpartisipasi untuk memberantas buta huruf, contohnya ibu-ibu PKK harus ikut serta, organisasi masyarakat (Ormas), mahasiswa yag sedang Kuliah Kerja Nyata $(\mathrm{KKN})$, dan anggota TNI yang mempunyai program TNI Manunggal Aksara.

Freire (1973) dalam Martikanto T dan Soebiato P (2013: 32-33) mengatakan bahwa kegiatan pendidikan orang dewasa (seperti halnya pemberdayaan masyarakat) merupakan.Proses penyadaran menuju kepada pembebasan. Oleh sebab itu, proses pemberdayaan masyarakat harus dibebaskan dari upaya-upaya menciptakan ketergantungan atau bentuk-bentuk penindasan. Artinya melalui pemberdayaan, penerima 
manfaat harus diberi kesempatan seluas-luasnya untuk menyampaikan pengalaman dan mengembangkan daya nalarnya, sehingga didalam proses pemberdayaan tersebut kedudukan tutor dan masyarakat yang buta huruf berada dalam posisi yang setara.

Penerapan teori konstruksi sosial dalam pekerjaan sosial. Peter L. Berger dan Thomas Luckman (1967) dalam Burhan (2007: 125) mengemukakan bahwa: Pekerja sosial sadar bahwa keinginan untuk membangun masyarakat yang masih rentan dari kesejahteraan membutuhkan alternatif-alternatif yang kiranya bisa diterapkan kepada masyarakat yang menyandang buta huruf. Seperti yang terjadi di Desa Bontomarannu saat ini, pekerja sosial mengalami distorsi terhadap permasalahan-permasalahan yang sedang dihadapi masyarakat desa yang buta huruf.Keikut sertaan pekerja sosial (pemerintah) dalam melihat problem masyarakat tentunya berpengaruh bagi laju perkembangan harapan hidup ke arah yang lebih baik.Seperti yang ditegaskan Clifford untuk mencari sumber masalah orang banyak, memerlukan keterampilan yang lebih.Dalam hal ini pekerja sosial adalah pemerintah yang ada di Desa Bontomarannu yang juga melihat masalah yang di hadapi masyarakat.Masalah tersebut adalah masalah buta huruf, dimana masyarakat masih banyak yang buta huruf.Untuk itu pemerintah melakukan upaya pengentasan buta huruf dengan memberdayakan masyarakat desa dan memberikan modal usaha kepada masyarakat. Dengan adanya program ini masyarakat sangat terbantu sudah bisa mandiri.

\section{METODE PENELITIAN}

Jenis penelitian yang dilakukan penelitian deskriptif kualitatif yang bertujuan untuk mendapatkan gambaran umum tentang pemberdayaan masyarakat desa yang buta huruf di Bontomarannu Kabupaten Takalar.Informan di tentukan secara purposive sampling, teknik pengumpulan data yaitu observasi, wawancara dan dokumentasi, dianalisis melalui tahapan pengumpulan data reduksi data, penyajian data, penarikan kesimpulan dan menggunakan tehnik keabsahan data triangulasi sumber, waktu, dan tehnik.

\section{PEMBAHASAN}

Pada sektor pendidikan di Kabupaten Takalar memegang peranan penting dalam peningkatkan Sumber Daya Manusia (SDM). Agar sumber daya manusia di kabupaten Takalar dapat bersaing dengan kabupaten lainnya dan memegang peranan minimal di Kabupatennya sendiri maka diperlukan suatu perencanaan untuk meningkatkan 
pendidikan di Kabupaten Takalar, termasuk Pendidikan Non Formal dan Informal. Tidak dapat dipungkiri bahwa masih banyak sekali sumber daya manusia di Kabupaten Takalar yang tidak berkompeten, hal ini dipengaruhi oleh tingkat pendidikan masyarakat yang rendah bahkan banyak masyarakat terutama di desa yang berada di daerah pesisir pantai kurang mengenyam pendidikan, sehingga mengalami buta huruf, kalau pun ada cuma orang-orang yang mampu yang bisa sekolah. Faktor yang menyebabkan masyarakat buta huruf adalah kemiskinan, ekonomi, putus sekolah kondisi sosial masyarakat, dan gender.Dalam rangka pelaksanaan program Pemberdayaan Masyarakat dan Pemberantasan Buta huruf ini, perlu dilakukan beberapa langkah agar dicapai pelaksanaan yang sesuai dengan apa yang diinginkan oleh penyelenggara. Langkahlangkah tersebut adalah sebagai berikut : a) Langkah Persiapan yaiut: (1) Sosialisasi, Sosialisasi program Pemberdayaan Masyarakat dan Pemberantasan Buta Huruf yang dilakukan oleh ketua PKBM pada perangkat desa dan tokoh masyarakat setempat untuk dipublikasikan kepada masyarakatnya dan Dalam melakukan sosialisasi dan penentuan identifikasi penyelenggara dan tutor dilaksanakan secara intensif oleh Ketua PKBM Satria Galesong yang melibatkan perangkat desa dan tokoh masyarakat setempat seperti Kepala Desa, Sekertaris. Hal ini karena mereka yang lebih mengetahui karakteristik desanya dan bisa mengidentifikasi kirakira siapa yang bisa menjadi penyelenggara. (2) Pendataan calon warga belajar, Pendataan merupakan kewenangan masingmasing desa yang bisa dilakukan oleh Kepala Desanya langsung atau Kepala Desa menunjuk tokohtokoh masyarakat setempat seperti PKK, Aisyiyah, atau pihakpihak yang memahami karakteristik desanya untuk melakukan pendataan secara langsung. Data yang diperoleh digunakan sebagai data dasar desa mana saja yang perlu diselenggarakan program pemberdayaan masyarakat desa yang buta huruf. Kepala desa diberi waktu maksimal 1 bulan dalam melakukan pendataan calon warga belajar yang ada di daerahnya masingmasing. Dari pendataan calon warga belajar periode tahun 2014/2015, terjaring 70 orang penyandang buta huruf diBontomarannu Kabupaten Takalar.Calon warga belajar sejumlah 70 orang tersebut terdiri dari 4 dusun. Yaitu Dusun Talisea, Dusun Balang, Dusun Mandi dan Dusun Barua. (3) langkah pelaksanaan, Pelaksanaan proses pembelajaran meliputi 3 tahapan : a) Tahap Pemberian Materi Dasar (Tahap I) Pada tahap pemberian materi dasar, materi yang diberikan adalah membaca, menulis dan berhitung. Tutor memberikan materi awal dengan mengenalkan huruf abjad kemudian membantu warga belajarnya untuk dapat menghafal hurufhuruf. b) Tahap Pembinaan Keterampilan (Tahap II) dilaksanakan, Setelah melalui tahap I, maka pada tahap II ini warga belajar 
akan diberi materi pembelajaran keterampilan. c) Tahap Pembinaan berkesenambungan (Tahap III) dilaksanakan, Pada tahap III ini warga dibina dan diberikan dana untuk mengembangkan keterampilannya.

Proses pembelajaran program pemberdayaan masyarakat desa yang buta huruf di rumah tutor dengan jadwal pembelajaran 3 kali dalam 1 minggu. Setiap kelompok belajar memiliki jadwal yang berbeda dengan kelompok belajar yang lain. Tahap I hingga tahap III, warga belajar juga diberi keterampilan fungsional, misalnya : cara memjahit, membuat kerajinan dari anyaman bambu, membuat song'ko guru dan kerajian dari anyaman lontar lainnya serta membuat tikar dari daun pandan. Serta pembentukan kelompok tani dengan berbagai hal yang dia ajarkan seperti cara membuat pupuk kandang, cara menanam padi dengan menggunakan alat, cara menanam jagung yang baik untuk mendapatkan hasil yang maksimal untuk mensejahterakan masyarakat.Kegiatan pembelajaran program pemberdayaan masyarakat desa yang buta huruf ini sudah mendapat dukungan dari Pemerintah yang berupa penyediaan sarana dan prasarana bagi warga belajar sehingga para warga belajar tidak dituntut untuk membayar sedikitpun. Sarana dan prasarana tersebut sangat standar berupa alat tulismenulis, namun sudah bisa mendukung berjalannya proses pembelajaran program pemberdayaan masyarakat desa yang buta huruf.

Hambatan selama proses pembelajaran, Dalam proses pembelajaran masih sering terjadi penundaan jadwal belajar, hal itu disebabkan karena banyak warga belajar yang memiliki motivasi belajar yang sangat rendah sehingga tidak menepati jadwal pembelajaran yang sudah ditetapkan. Banyak warga belajar yang tidak mau datang kalau tidak dijemput oleh tutornya sendiri, ada yang malu untuk ikut kegiatan belajar, ada yang dengan alasan banyak pekerjaan maka mereka mengurungkan niatnya untuk belajar, atau bahkan ada yang memang malas untuk ikut belajar. Hambatan yang paling dirasakan yaitu ketidak mampuan warga belajar dalam mengikuti proses pembelajaran, sehingga secara kualitas masih ada yang belum optimal dalam menguasai materi pembelajaran. Tindak lanjut yang dilakukan oleh penyelenggara adalah melakukan program Jaring Garap. Program Jaring Garap ini bertujuan untuk membelajarkan kembali para warga belajar yang belum benarbenar mampu menguasai materi pembelajaran.Selain hambatanhambatan di atas masih terdapat faktor hambatan dalam pelaksanaan program pemberdayaan masyarakat desa yang buta huruf yaitu sebagai berikut: a) Nilai-nilai Sosial yang dimaksud adalah Adanya sikap masyarakat yang tidak mau dan malu menginformasikan bahwa ada diantara diri masyarakat yang buta huruf. b) Mata 
pencaharian, pelaksanaan program pemberdayaan masyarakat desa yang buta huruf juga terhambat masalah mata pencaharian warga belajarnya, dimana warga belajar lebih memilih mencari uang dari pada mengikuti proses pembelajaran. Hal ini menyebabkan saat warga belajar merasa ada peluang mencari uang, maka mereka akan meninggalkan pembelajaran. Permasalahan ini tidak dapat dihindari dan tutor juga tidak berhak melarang karena warga belajar juga membutuhkan pekerjaan untuk bertahan hidup. c) Motivasi penduduk, Permasalahan yang paling mendasar dalam pemberdayaan masayarakat desa yang buta huruf yaitu rendahnya motivasi belajar penduduk buta huruf. Minimnya pengetahuan masyarakat tentang pendidikan juga sangat berpengaruh terhadap kelancaran pelaksanaan program pemberdayaan masyarakat desa yang buta huruf mereka tidak merasa membutuhkan pendidikan karena mereka menganggap itu tidak penting sehingga mereka kurang respon terhadap program ini.Tujuan Pelaksanaan Program pemberdayaan masyarakat desa yang buta huruf adalah Meningkatkan pengetahuan membaca, menulis, berhitung, dan tematik serta keterampilan fungsional untuk meningkatkan kualitas sumber daya manusia dan masyarakat agar mampu berperan serta secara aktif dalam pembangunan dan mampu meningkatkan efisiensi dan produktivitas bagi peningkatan kesejahteraan hidupnya. Memberi bekal keterampilan kepada warga belajar agar dapat mandiri.Dengan dilaksanakannya program pemberdayaan masyarakat desa yang buta huruf maka dampak sosial yang diharapkan terjadi pada kehidupan masyarakat yaitu masyarakat mampu berinisiatif dan memiliki kemandirian dalam kehidupannya sehinga tidak menggantungkan diri pada orang dan berpikiran untuk maju. Selain itu juga diharapkan masyarakat sudah memiliki kemampuan keaksaraan sehingga mampu melakukan berbagai kegiatan yang berhubungan dengan keaksaraan dan mampu mengakses informasi dalam bentuk tulisan seperti koran dan majalah.

Setelah pelaksanaan program pemberdayaan masyarakat desa yang buta huruf ini, dampak ekonomi yang diharapkan pemerintah bagi masyarakatnya adalah masyarakat mampu berwirausaha secara mandiri dengan bekal keterampilan yang telah diberikan selama program pemerintah ini berlangsung. Dengan begitu, apa yang menjadi tujuan pemerintah dapat tercapai. Dampak yang diharapkan pemerintah dengan diselenggarakannya program pemberdayaan masyarakat desa yang buta huruf telah tercapai. Hal itu terbukti dengan adanya kemajuan warga belajarnya dibidang sosial maupun ekonomi, yaitu secara sosial masyarakat yang dulunya buta aksara sekarang telah mampu membaca, menulis, dan berhitung sedangkan secara ekonomi masyarakat mampu berwirausaha secara mandiri dengan menerapkan materi keterampilan fungsional yang 
telah diberikan dalam proses pembelajaran program pemberdayaan masyarakat desa yang buta huruf yang dilaksanakan oleh PKBM Satria Galesong.

\section{KESIMPULAN}

1. Faktor-faktor yang menyebabkan masyarakat desa yang buta huruf yaitu faktor kemiskinan, faktor ekonomi, faktor putus sekolah, faktor kondisi sosial masyarakat seperti kesehatan dan gizi masyarakat, geografis, aspek sosiologis, dan issue gender, dan penyebab struktural seperti skala makro, skala mikro, aspek kebijakan.

2. Pelaksanaa program pemberdayaan masyarakat desa yang buta huruf dilaksanakan oleh pemerintah bersama PKBM (Pusat Kegiatan Belajar Masyarakat) PKK dan Aisiyah. Pelaksanaan program ini meliputi 3 tahap di antaranya: Tahap pertama pemberian materi dasar (seperti: membaca, menulis, dan berhitung), Tahap kedua: Pembinaan Keterampilan, dan Tahap Ketiga: Pembinaan secara bersikenambungan.

3. Hambatan pelaksanaan dalam program ini adalah dipengaruhi oleh nilai-nilai sosial, sosialisasi yang kurang, mata pencaharian, motivasi penduduk yang kurang sehingga masyarakat tidak terlalu peduli, dana, kurangnya motivasi tutor.

\section{DAFTAR PUSTAKA}

Adi, R, I. (2013). Kesejahteraan Sosial (Pekerjaan Sosial, Pembangunan Sosial, dan Kajian Pembangunan). Jakarta : Rajawali Pers.

Anwas, O, M. (2014).Pemberdayaan Masyarakat di Era Global.Bandung : Alfabeta.

Azzet, M, A. (2014). Pendidikan Yang Membebaskan.Jogjakarta: Ar-Ruzz Media.

Freire, P. (1999). Politik Pendidikan, Kebudayaan, Kekuasaan, dan Pembebasan. Yogyakarta : Pustaka Belajar.

(2008). Pendidikan Kaum Tertindas.Jakarta : Pustaka LP3ES Indonesia.

Hiryanto.(2008). Kebijakan Program Pemberantasan Buta Aksara.Tesis. Yogyakarta: PLS FIPs UNY

Labolo, M. (2014).Memaham illmu Pemerintahan: Suatu Kajian, Teori, Konsep, dan Pengembangannya. Jakarta: Rajawali Pers.

Poloma, M. M. (2013). Sosiologi Kontemporer. Jakarta: Rajawali Pers.

Pranarka A. M. W. dan Prijono Onny S, (1996). "Pemberdayaan : Konsep, Kebijakan dan Implementasi". Jakarta : CSIS. 
Mardikanto, T. \& Soebiato, P. (2013).Pemberdayaan Masyarakat Dalam Perspektif Kebijakan Publik. Bandung :Alfabeta.

Ritzer, G. (2011).Sosiologi Ilmu Pengetahuan Berpara digma Ganda. Jakarta: Raja Grafindo Persada.

Salman, D. (2012). Sosiologi Desa : Revolusi Senyap dan Tarian Kompleksitas. Makassar : Ininnawa.

Scott, J. (2012). Teori Sosial Masalah-masalah Pokok Dalam Sosiologi.Yogyakarta : Pustaka Pelajar.

Soekanto, S. (2012).Sosiologi Suatu Pengantar. Jakarta: Rajawali Pers.

Suharto, E. (2014). Membangun Masyarakat Memberdayakan Rakyat. Bandung: Refika Aditama.

Suyanto, B. (2013).Anatomi Kemiskinan dan Strategi Penanganannya.Malang : In-Trans Publishing Wisma Kali Metro.

Wirawan, I, B. (2012).Teori-Teori Sosial Dalam Tiga Paradigma (Fakta Sosial, Definisi Sosial, dan Perilaku Sosial). Jakarta: Kencana.

Sumardi K. (2009). Pendidikan Keaksaraan Dasar Melalui Metode Kombinasi Bagi Wanita Miskin dan Tuna Aksara di Pedesaan Indonesia.(Online). Diakses pada tanggal 28 April 2015

Permana, Heru Hairudin. (2011). Buta Huruf.(Online). (http://herhaiper.blogspot.com//2011/06/buta-huruf.html. Diakses pada tanggal 28 April 2015. 